\title{
FEUDALISM IN AFRICA?!
}

\section{By JACK GOODY}

Was feudalism a purely Western phenomenon? Is it a universal stage in man's history, emphasizing replacement of kinship by ties of personal dependence which further social development required? If it is neither a universal prerequisite nor yet exclusively Western, what are the conditions under which it is found? A host of such questions are raised by the consistent use both by historians and sociologists of the term 'feudal' as a description of the societies they are studying. Here I want to inquire into the implications and value of the concept as applied to African societies.

First used, apparently, in the seventeenth century, ${ }^{2}$ the word feudal has since served an astounding variety of purposes, in everyday speech as well as in the writings of historians and sociologists. The primary referent is of course to a particular historical period, to Western Europe between the ninth and thirteenth centuries, to the social systems that on the one hand superseded the Roman Empire and the 'tribal' régimes which destroyed it, and that on the other hand preceded first mercantile and then industrial 'capitalism'. But the term has also been used of innumerable societies other than those of medieval Europe. A recent survey (Coulbourn, 1956) includes a comparison of feudalism in Japan, China, Ancient Egypt, India, the Byzantine Empire, and Russia. Nor is this simply an editorial quirk. $^{3}$ Many earlier writers on Japan had written of its feudal institutions; ${ }^{4}$ Marcel Granet entitled his study La Féodalité chinoise (1952); Pirenne and

${ }^{1}$ An earlier version of this paper was read to the African History Seminar of the University of London in May 1962 , and I am grateful not only for the comments of those who attended, but also to the other contributors, whose papers were later circulated to me. Some of these, like Dr Mair and Mrs Chilver, were certainly better qualified to discuss the African studies, and I had already made use of their work. Others like Professor Helen Cam, who wrote on English feudalism, dealt much more adequately with the non-African material. My thanks are particularly due to Dr John Fage, who raised with me a problem I touch upon in the course of this essay, namely, what contribution a medieval historian could make to the study of African society were he to immerse himself in that material. For an illuminating treatment of some of the general problems that lie behind this discussion, the reader should turn to E. E. Evans-Pritchard, Anthropology and History (Manchester, 1 $96 \mathrm{r}$ ).

'In the sense of 'pertaining to the feudal system'. Of related words, some like feudary were used much earlier while others like feudalism were neologisms of the nineteenth century. The historian's discovery of the feudal system dates from the time of Cujas and Hotman in the sixteenth century. See J. G. A. Pocock, The Ancient Constitution and the Feudal Law; a Study of English Historical Thought in the Seventeenth Century (Cambridge, 1957), $70 \mathrm{ff}$.

3 See also Carl Stephenson, Mediaeral Feudalism (1942), 1-2.

4 See also Marc Bloch, Feudal Society' (1961), 446-70, and Robert Boutruche, Seigneurie et féodalité (1959), $217-97$, 
Kees discuss the question in dealing with Egypt; Kovalevski and BadenPowell do the same with regard to India and Vasiliev for Byzantium.

Historians are not the only persons to use this term in a comparative context. Social anthropologists have employed it in an equally allembracing way. Roscoe and others have seen the Baganda as 'feudal', Rattray the Ashanti, Nadel the Nupe of northern Nigeria. Indeed it would be difficult to think of any state system, apart from those of Greece and Rome, upon which someone has not at some time pinned the label 'feudal'. And even these archaic societies have not been left entirely alone. Feudal relationships have been found in the Mycenean Greece revealed by the archaeologists and epigraphers, while it is generally agreed that one element in medieval feudalism was the institution of precarium of the later Roman Empire. ${ }^{5}$

Unless we assume the term has a purely chronological referent, then, or unless we are to take our smug refuge in the thought that persons, events, and institutions defy comparison because of their uniqueness, the use of any general concept like feudal, more particularly concepts like fief or client, must have comparative implications. Marc Bloch realized this when at the end of his classic study he wrote, 'Yet just as the matrilineal or agnatic clan or even certain types of economic enterprise are found in much the same forms in very different societies, it is by no means impossible that societies different from our own should have passed through a phase closely resembling that which has just been defined. If so, it is legitimate to call them feudal during that phase.' (Bloch, $1961: 446$.)

There is then a measure of general agreement that 'feudal' should be used in comparative work. Here I want to look briefly at the ways in which it has been employed in the African context. For a large number of political systems of the 'state' type have been called 'feudal', and it seems pertinent to try and find out what the authors are getting at.

There are times when it seems as if people who work in the nonEuropean field use the term 'feudal' in the same spirit that led the composers of the chansons de geste to link the histories of their own petty kingdoms on the Atlantic seaboard with the great civilizations of the Mediterranean world; new-comers, upstarts, nouveaux riches, thus acquire the aura of respectability that tradition imparts. The danger in this is apparent. If the term has high status in the comparative study of society, there will be a tendency constantly to widen its range of meanings for reasons other than those of analytic utility. Moreover, an attachment to Western European models may turn out to be not the embrace of respectability but the kiss of death, just another version of the old pre-Copernican fallacy of the universe revolving around the earth.

- The precarium was a grant of land to be held by someone during the pleasure of the donor: the land was a boon (beneficium) granted as the result of the prayer (preces) of the recipient (Stephenson, 1942: 7; Pollock and Maitland (2nd ed.), 1898: 1, 68 n.r). This practice has been the subject of an extensive discussion over the relative influence of German and Roman institutions upon feudal Europe. 
One major difficulty in using the term for comparative purposes is that, even for historians of Europe, it has many meanings. In his introduction to the translation of Bloch, Postan writes of a recent Anglo-Soviet discussion on feudalism in which the two sides 'hardly touched at a single point. The English speaker dwelt learnedly and gracefully on military fiefs, while the Russian speaker discoursed on class domination and exploitation of peasants by landlords' (Bloch, I96I : xiii). These different views represent variants of two rather broader categories of approach which Strayer has summed up in the following words: 'One group of scholars uses the word to describe the technical arrangements by which vassals become dependents of lords, and landed property (with attached economic benefits) became organized as dependent tenures of fiefs. The other group of scholars uses feudalism as a general word which sums up the dominant forms of political and social organization during certain centuries of the Middle Ages' (1956: 15).

One can discern two trends in the narrower technological use of the term feudal. The first points to its derivation from 'fee', and hence to dependent land tenure. ${ }^{6}$ The second emphasizes the lord-vassal relationship; it was to draw attention to this aspect of 'feudalism' that Pollock and Maitland suggested the term be replaced by 'feudo-vassalism' (r $898: 1,67)$. In general, however, the core institution of feudal society is seen as vassalage associated with the granting of a landed benefit (fief), usually in return

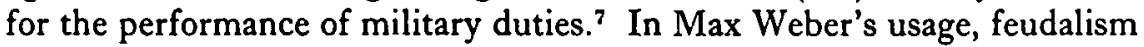
is 'the situation where an administrative staff exists which is primarily supported by fiefs' (1947: 322).

The wider use of the term also has its variants, each with its own body of supporters. Apart from the loose popular turn of phrase that sees all types of hierarchical status (with the possible exception of slavery and bureaucratic office) as 'feudal', there are two main trends, one relating to political structure, the other to economic conditions. Political factors are stressed in the Coulbourn symposium, where Strayer summarizes this view in the following words: 'Feudalism is not merely the relationship between lord and man, nor the system of dependent land tenures, for either can exist in a non-feudal society. ... It is only when rights of government (not mere political influence) are attached to lordship and fiefs that we can speak of fully developed feudalism in Western Europe' (1956: I6).

- e.g. N. D. Fustel de Coulanges, Les Origines du systeme féodal: le bénéfice et le patronat pendant l'époque mérovingienne (Histoire des institutions politiques de l'ancienne France), Paris (1890), p. xii.

'Although fiefs are usually thought of as based upon the tenure of land, money-fiefs also played an important part in the West; they were of even greater significance in the Crusader Kingdom of Jerusalem (Sir Steven Runciman, The Families of Outremer (London, 1960), 5). Kosminsky (and others before him) has pointed out that the bulk of manorial incomes took the form of money-rents rather than 'feudal' services. See E. A. Kosminsky, Studies in the Agrarian History of England in the Thirteenth Century (ed. by R. H. Hilton, trans. by Ruth Kisch) (Oxford, 1956) (1st pub. Moscow, 1947) and the review by M. Postan, 'The Manor in the Hundred Rolls', Economic History Review, and ser., 3 (1950-1), I19-25. 
The thesis that feudalism is essentially a locally centred form of government is clearly connected with the existence of fiefs. Dependent tenures create (or recognize) a local administration of the fief-holder and those who inhabit his estate; they constitute a devolution of powers and are associated with a weakly centralized government that depends upon vassalage to provide military support.

The other line of thinking stresses the economic aspects and sees these as characteristic of a type of productive system. This was of course Marx's approach. He saw feudalism as one of the stages of pre-capitalistic economies, a 'natural economy' which preceded and led into the commodity market system. Changes in the division of labour were accompanied by different forms of property ("the stage reached in the division of labour... determines the relations of individuals to one another with respect to the materials, instruments and product of labour'): the first form is tribal property, the second the communal and State property of antiquity; the third form is feudal or estates property ( $1845-6$ : I $15-19$ ).

Finally, the various political and economic features are clearly linked together in practice (though the analytic nature of the connexion is open to discussion), and there is a comprehensive approach that tries to define feudalism in terms of a number of these associated institutions. Such is the conclusion to Marc Bloch's study of feudal society, where he begins the section entitled 'A cross-section of comparative history' with the words 'A subject peasantry; widespread use of the service tenement (i.e. the fief) instead of a salary, which was out of the question; the supremacy of a class of specialized warriors; ties of obedience and protection which bind man to man and, within the warrior class, assume the distinctive form called vassalage; fragmentation of authority . . . such then seem to be the fundamental features of European feudalism' (196r: 446).

Each of these approaches to feudalism has been used by different authors in analysing the pre-colonial régimes of Africa. But the most explicit attempts to compare these political systems with medieval Europe have been in the work on northern Nigeria and the Interlacustrine Bantu, especially in the accourts given by Nacel of Nupe and by Maquet of Ruanda.

A section of Nadel's study, $A$ Black Byzantium (1942), is actually entitled 'The Feudal State', and here the author describes the manner in which tribute was coilected and how the kingdom was divided into units of different sizes ('counties'), each comprising 'a town with its dependent villages and tunga which were administered as fiefs through feudal lords or egba' (p. I I 7). These lords, who were recruited from the royal house, the office nobility, or the Court slaves, were eligible for promotion to more lucrative fiefs, although they continued to reside in the national capital. They constituted a 'feudal nobility' who played an in portant part in raising military forces for the king, especially through their personal 'clients'. 
The institution of clientship (bara-ship), which is widespread in the States of northern Nigeria, consists in a voluntary declaration of allegiance for the sake of political protection and often provides the basis for the formation of factions. There are a variety of forms, some of which involve military service, but Nadel sees the institution as essentially comparable to the patrocinium of Imperial Rome and medieval Europe (1942: 122-3).

In his recent study of one of the Hausa states, M. G. Smith analyses the changes that have occurred over the last hundred and sixty years in a rather similar political system. In the Hausa kingdoms, he writes, government 'is conducted through a system of ranked and titled offices known as sarautu ... each of which can be regarded as an exclusive permanent unit, a corporation sole. These titled offices are characterized by such attributes as fiefs, clients, praise-songs, allocated farmlands, compounds and other possessions ...' (1960: 6).

In Zaria, as in Nupe (but unlike most of the Hausa states), offices were not generally hereditary except for kingship and the major vassal chiefships. The power and ambitions of fief-holders were controlled by the fact that they were clients of the king. Clientage (again there were a number of forms of bara-ship) is defined as 'an exclusive relation of mutual benefit which holds between two persons defined as socially and politically unequal and which stresses their solidarity' (r960: 8).

There is an interesting difference between the accounts of Nupe and Zaria. Whereas Nadel deliberately speaks of 'a feudal system', as Lombard does for the near-by Bariba of northern Dahomey (1957, 1960), Smith is content to use 'fief' and 'client' as analytic tools without making any overall comparison with medieval Europe.

We find another similar situation in recent accounts of the states of the Interlacustrine Bantu of East Africa. In his study of the Ruanda, The Premise of Inequality in Ruanda (1961), ${ }^{8}$ Maquet describes the political system as a feudal structure. He defines a feudality as an organization 'based on an agreement between two individuals who unequally partake in the symbols of wealth and power culturally recognized in their society. The person who, in that respect, is inferior to the other, asks the other for his patronage, and, as a counterpart, offers his services. This is the essence of the feudal régime...' (196ra: 133$)$. The term 'agreement' here is preferred to contract because the freedom not to enter into clientship was illusory, since no Ruanda could afford to live without a lord. Clients might belong to the ruling estate of cattle-keepers (the Tutsi) or to the subordinate group of agriculturalists (the $H u t u)^{\theta}$ but in both cases the transaction was

'See also his general discussion, 'Une hypothèse pour l'étude des féodalités africaines', Cahiers d'études africaines, II (1961), 292-314.

- i.e. what Lombard speaks of as the lord-vassal (liens de vassalité) as well as the patronclient relationship (liens de clientèle) (1960: I I). More usually vassalage implies military service; according to Stephenson the term should be restricted to 'an honorable relationship between members of the warrior class' (1954: 250, n. 6r); see also Boutruche, Seigneurie et fédalité (1959), $293 \mathrm{ff}$. 
established by the loan of cattle to the inferior partner, a transaction which Maquet regards as equivalent to the allocation of a landed fief in feudal Europe (1961a: 129,133 ). ${ }^{10}$ But he claims that the fief itself is only rarely found in Africa, because unlike medieval Europe, the tenure of land is not based upon Roman law (196rb: 294). By this I think the author means that a political superior (such as a king) does not 'own' the land in the same way as a feudal lord in Western Europe, i.e. in the same way a Tutsi 'owns' cattle, or the Nupe king 'owns' tribute. Hence the characteristic feudal formula of $Y$ holding land of $X$ (tenere terram de $X$ ) could nut be applied. There is a certain truth in this observation, but it should be remembered that in England, at least, the formula of dependence seems to have been applied to a number of very varied conditions. The bundle of rights which we may think of as complete ownership of land was not always distributed among the actors and groups involved in precisely the same way and the nature of dependence differed in each case. Moreover, such relationships always contained an element of mutuality. From one point of view all higher contracts depended upon the performance of the basic agricultural tasks, and from the evidence concerning the inheritance of land at the village level it would seem that here the idea that conquest put all rights in the hands of the Norman conquerors was something of a fiction. Whatever the legal position on this abstract level, the medieval system in practice appears to display some similarities with African land tenure, especially in states like Nupe. ${ }^{11}$

Clientship in East Africa is also discussed by Lucy Mair in her recent book dealing with the political systems of East Africa (Primitive Government, 1962) and in a general paper on 'Clientship in East Africa' (1961). ${ }^{12}$ As a minimum definition she suggests: 'a relationship of dependence not based upon kinship, and formally entered into by an act of deliberate choice' (196r: $\left.3^{1} 5\right)^{13}$ She goes on to discuss the institution as it existed both among the cattle-keeping Ruanda and Ankole, and among the predominantly agricultural Ganda and Soga. Ruanda clientship was established by a cattle transaction, initiated by the would-be client with the words 'Give me milk; make me rich; be my father'; but the relationship was entered into because of a universal need for protection rather than for purely economic reasons. Among the Ganda and Soga on the other hand, society was divided into landlords and peasants, the former being subordinate territorial chiefs chosen by the king, who had control of unoccupied

${ }^{10} \mathrm{Mrs}$ Chilver points out that it bears a closer resemblance to the Early Irish form of cattle-clientage, celsine (r960: 390).

${ }^{11}$ For a discussion of the medieval situation, see Pollock and Maitland (1898: 1, 234; II, 4ff.); for Africa, see Max Gluckman, 'African Land Tenure', Rhodes-Livingstone Institute Yournal, 5 (1945), I-12; for the concept of a bundle of rights, see Sir Henry Maine, Ancient Law (1861) and Dissertations on Early Law and Custom (London, 1883), 344.

${ }^{12}$ For two stimulating studies of particular societies with clientship institutions, see A. W. Southall, Alur Society, and L. A. Fallers, Bantu Bureaucracy (for the Soga).

${ }^{13}$ Residual categories often give rise to difficulties of analysis and this may prove to be so in the present case, where clientship is defined negatively in respect to kinship. 
land. Mair speaks of the relationship established by the transfer of rights in land from chief to peasant as analogous to that of patron-client (a 'passive clientage', since personal service is absent); but she reserves the use of the term in the strict sense to the relationships between the king and his territorial rulers ('client-chiefs') and to that between an office-holder and his personal retainers ('private clientship'), from among whom client-chiefs were sometimes recruited (Mair, 1961 : 322-3; Fallers, n.d.: (35).

Dr Mair also observes that clientship is a basis of social differentiation in two ways, firstly because 'it creates formally recognized relationships of superiority and subordination, defined by other criteria than seniority', ${ }^{14}$ and secondly because in some societies such as Buganda 'it is the main channel of social mobility' (1961: 325).

We earlier saw that historical approaches to the definition of feudalism could be roughly classified into the technical and the general. These two sets of studies of societies in northern Nigeria and in the Interlacustrine region have been concerned with institutions similar or analogous to those which are the subject of the technical analysis of feudalism, namely clientship (or rather vassalage) and fiefs. But whereas Nadel and Maquet feel impelled to describe the societies they have studied as 'feudal', Smith, Fallers, and Mair make at least as adequate an analysis without introducing the concept at all. This second approach seems preferable as a procedure. It is simpler; it minimizes the inevitable Western bias; and it helps to avoid the assumption that because we find vassalage (for example), we necessarily find other institutions associated with it in medieval Europe. It is just these supposed interconnexions which comparative study has to test rather than assume.

I turn now to discussing the way in which the general approach to the study of feudal institutions has been used in work on Africa, beginning with the political. Strayer emphasizes that in medieval Europe many governmental functions were carried out at the local level, and Coulborn goes on to suggest that feudal systems are 'a mode of revival of a society whose polity has gone into extreme disintegration', i.e. after the break-up of a great empire (1956: 364 ; see also Hoyt, 1961 ). Here is an instance where the Western European starting-point heavily influences the outcome of the analysis. If we are to take as characteristic of feudalism the features that Strayer discusses at the beginning of the volume (i.e. clientship, fiefs, locally centred government), then it would seem that these institutions are not only to be associated with the revival of government after an earlier collapse. Indeed the African material points clearly to the fact that they may also occur as chiefless communities develop more centralized governments.

Southall touches upon this problem in his study of the Nilotic Alur of East Africa. His general purpose is to examine the 'process of domination'

\footnotetext{
14 See Fallers on the Soga (n.d.: 230).
} 
by which Alur dynasties become rulers of neighbouring, chiefless communities. In the course of his book, he discusses 'the embryonic political specialization of the Alur', which he sees as intermediary between chiefless societies on the one hand and state systems on the other (n.d.: 234). On the one hand he sees the Alur as introducing 'a new principle in the regulated allegiance of one man to another without any kinship bond existing between them' (p. 234), as in the relation of chiefs with their subjects, of nobles with their domestic serfs, and of chiefs with their various dependents. On the other hand, the Alur have no bureaucracy. 'The embryonic administrative staffs possessed by chiefs in their envoys and courtiers never acquired any formally defined administrative or jural powers, and remained occasional agents, advisers and confidants of their chief' (p. 240). Thus this type of political system, he concludes, is intermediary between what Fortes and Evans-Pritchard (1940) spoke of as state systems with an administrative organization (type A) and segmentary lineage systems (type B). Southall calls it the 'segmentary state' (as contrasted with the 'unitary state') and distinguishes as one of its most characteristic features the way in which both local and central authorities exercise very similar powers. ${ }^{15}$

In a section entitled 'The temporal and spatial range of the segmentary state', Southall goes on to consider other societies of this type, among which he includes the Ashanti, the Yoruba, Anglo-Saxon England, and 'feudal France in the eleventh century' (pp. 252-56). ${ }^{16}$ While he does not specifically equate feudal and segmentary state systems, he does include eleventh-century France as an example of the segmentary state and it is his analysis of this kind of system which bears directly upon a central problem of the Coulborn symposium on feudalism; namely, the question of political centralization. ${ }^{17}$ And it is clear from the Alur case that we may expect to find such locally centred régimes developing with an increase in administrative centralization as well as after the disintegration of an even more centralized system. This evidence suggests that the latter hypothesis is one of the European derived variety that we have to beware of. True, the sort of breakdown and build-up of central organization that occurred in Western Europe after the withdrawal of Roman rule is likely to give rise to specific institutional forms which warrant comparative treatment (for this

${ }^{15}$ Six characteristics are listed by Southall (pp.: 248-9), but the distribution of power is basic to them all.

${ }^{10}$ As Stenton notes, the conquest state of Norman England did not display the same local independence in governmental matters that characterized feudal régimes elsewhere in Europe (1961: 5, 12-15). Unlike Maitland, Stenton emphasizes the differences in the English social system resulting from the Norman Conquest and asserts that 'only the most tentative of approaches had been made before the Conquest towards the great feudal principle of dependent tenure in return for definite service' $\left(196_{1}: 123\right)$. On the other hand, as Barlow remarks, 'most of the features associated with true feudalism can be found in the Old-English Kingdom' ( $1961:$ I 1 ).

17 Maquet has a rather different line-up. He sees the coercive sanctions of governments as operating permanently (i.e. in states) or intermittently (i.e. in non-states.) Feudality makes its appearance in both types of systems, but not in states of a despotic kind. 
situation is not in itself unique). But such comparison needs to include societies like the Alur which are in the initial process of centralization as well as those which are undergoing a secondary process. Only in this way can a satisfactory attempt be made to isolate those institutions that are linked with one process rather than the other, and those that are associated with both.

Clientship (as Southall, Maquet, and Mair see it) can certainly occur in both these situations. Indeed Southall and Mair regard this form of personal dependence as an essential element in the development of centralized institutions (Southall, n.d.: 234; Mair, 1962: 107 ff.). Mair sees the elements necessary for this process as present even in a chiefless society like the Nuer, an extreme example of polities of type B. The factors crucial to the development of kingship (and so of government which revolves round a single centre-pin) are two: the belief that ritual powers are hereditary and the ability to attract and keep a following. A privileged descent group, privileged perhaps by virtue of first arrival, is able to expand by attracting attached and client groups; individuals are able to increase the range and extent of their authority by acquiring followers other than their own kin (p. 122). By these and similar processes, diffuse government gives way to minimum government and eventually to yet more centralized forms. Or, as Southall puts it, kin-based, chiefless societies develop into segmentary states and these to unitary states. Certain of the institution thoughts of as characteristic of feudal societies, namely, clientship and locally centred government, are characteristic of the second phase of this process. ${ }^{18}$

The discussion which I have outlined in this rather summary way has a direct bearing not only on the question raised in the title to this paper but also to some wider problems that face historians and other students of African societies. But to these points I will return after briefly considering what I have called, for want of a better label, the economic approach to feudalism; that is, the approach which defines feudal institutions primarily with reference to economic features, in particular the mode of land holding.

Any degree of political centralization entails specialized roles and hence some withdrawal of man-power from primary production into administri:tive activity. To this extent at least all chiefs and lords 'live off the land', and usually have rights in land of a more far-reaching kind. But other more specific features are sometimes regarded as characteristically feudal--certain fiscal arrangernents, ${ }^{19}$ the seignorial mode of estate management, dependent tenure itself. Here I shall confine my remarks to the approach often adopted by orthodox Marxists, more particularly by I. I. Potekhin

\footnotetext{
${ }^{18}$ In a similar way L. A. Fallers, using Weber's typology of authority and Parsons's schema of pattern variables, describes the authority structure of the pre-colonial Soga as particularistic in contrast to the universalistic type of social relations that characterize bureaucratic structures; personal clientship is of course a particularistic tie of this kind (Fallers, n.d.: $238 \mathrm{ff}$.).

${ }^{10}$ Mrs Chilver (1960: 385) discusses these fiscal arrangements in examining East African states.
} 
in his paper, 'On Feudalism of the Ashanti'. ${ }^{20}$ Potekhin writes that 'Feudal land ownership constitutes the foundation of feudal relations.' Land belongs to a restricted circle of big landowners, while the peasant pays rent or performs services for the right to cultivate his land. In Ashanti, he finds 'the exclusive concentration of land in the hands of the ruling upper strata', together with the conditional land tenure and hierarchies of dependence 'typical of feudal society'. I have earlier commented that the idea of exclusive land tenure is hardly an accurate representation of the medieval evidence; it appears even less satisfactory as an interpretation of the Ashanti situation in the nineteenth century. To deny that 'ownership' of land is exclusively vested in one strata is not of course to assert that Ashanti (or medieval Europe for that matter) was a 'classless' (i.e. unstratified) society. It is simply to state, firstly, that the concept of 'absolute ownership' of land (as distinct from other means of production) is probably applicable only to a society dichotomized into slaves and freemen. ${ }^{21}$ Secondly, the splitting of the total quantum of rights in land between two individuals or groups does not necessarily imply a simple relation of dependency; delegation upward or devolution downward would give rise to much the same overall pattern. And lastly, it should be borne in mind that in pre-colonial conditions in Africa land was sometimes of little economic importance; for relatively low population densities (as compared, say, with Europe and Asia) meant that, in many regions, land was not a very scarce resource and hence its tenure could hardly provide the basis of differentiation for the 'class' system.

Before I conclude the discussion of the way in which the broader approaches to feudalism have been applied, let me recapitulate my comments upon the narrower technical approach. I remarked earlier that at this point in our inquiries I could see no great profit (and possibly some loss) in treating the presence of clientship or fiefs as constituting a feudality (e.g. Nadel and Maquet), as against analysing these institutions without inviting any overall identification of these societies with those of medieval Europe (e.g. Smith and Fallers). There seems even less to be gained from the view which sees African societies as feudalities on the basis of wider political or economic criteria. Firstly, there is the ever-present ambiguity of the term itself; and then again the primary referent is to a particular period in European history, and an author employing an analytic tool of this kind tends to focus the whole analysis around the Western situation. The difficulties are nowhere clearer than in the writings of those who see the development of human society in terms of the stages so widely used in

${ }^{20}$ Presented at the Twenty-fifth International Congress of Orientalists, Moscow, 1960. See also Basil Davidson, Black Mother, $33 \mathrm{ff}$., where he maintains that writers on African states have often called slavery what was in fact a form of feudal vassalage (p. 38); he speaks of 'African feudalism' (as found, for example, in Ashanti) as 'tribal feudalism' (p. 46). For a contrary view, see Maquet, 196rb: 296-8, 307-ro.

"On the important analytical difference between land and other property, see Pollock and Maitland, 1898: II, 2, and J. Goody, Death, Property and the Ancestors (1962), $292 \mathrm{ff}$. 
the latter half of the nineteenth century. Writers who adhere to the orthodox Marxist doctrine, formulated a hundred years since, are particularly apt to fall back upon the idea of a universal progression from tribalism to slavery, feudalism, capitalism, and finally socialism, each such stage being characterized by a particular set of social institutions. Most historians assume a rather similar scheme, either explicitly or implicitly, and, like some sociologists, tend to speak of tribal or kinship societies in a way that suggests that they too easily overlook the strength of their own attachments to family and tribe.

Of course, certain general trends of development in political, legal, and economic institutions are rightly accepted by all students of society and the study of these trends has often gained much from the approach associated with the names of Marx and Engels. ${ }^{22}$ What blocks advance, here as in other fields of comparative studies, is a rigid attachment to particular European-based schema, whether this be derived from an explicit ideological commitment or from an inability to see beyond our own cultural tradition. For an example of the influence exercised by the particular European story, I turn to Davidson's account of the history of slavery in Africa. To support his contention that the servile institutions of indigenous Africa were essentially similar to vassalage in feudal Europe (rather than the slavery of Classical times), he remarks that they coexist with other 'feudal' institutions, namely, 'the titles and rights of great lords, the obligations of the common people, the custom of trade and tribute, the swearing of fealty, the manners of war' (196r: 34 ). Quite apart from the generalized nature of some of these items, a generality which only extensive cross-cultural research could fully reveal, this approach takes the European evidence as its baseline, and assumes the very correlations that stand in need of proof.

To suggest that there appears little to be gained by thinking of African societies in terms of the concept of 'feudalism' implies neither a rejection of comparative work that includes European society, nor yet of the contribution the European medievalists can make to the study of African institutions. The last point first. Although historians of the Middle Ages are dealing with their own cultural tradition, they are mostly writing about a very different set of customs from those they have absorbed with their mother's milk. While their analysis is sometimes inhibited by the problem of origins, by a preoccupation with medieval institutions as the germ of contemporary ones, they are, on the other hand, forced to consider a broader range of human experience than historians who deal with more recent times. In this task they have been greatly helped by the legal historians who contributed so much to the study of the medieval period, and the extent of whose contribution was due in some measure to the wide interests of comparative jurisprudence in the latter half of the nineteenth century. For a direct line runs from Fustel de Coulanges and Maine to

\footnotetext{
32 e.g. in the writings of V. Gordon Childe. For a general account of the influence of Marx on the social sciences, see Bottomore and Rubel, 1956.
} 
Vinogradoff and Maitland, all men who had a considerable acquaintance with ethnological studies as well as with historical material. For Vinogradoff, 'comparative jurisprudence is one of the aspects of so-called sociology, being the study of social evolution in the special domain of law'; it draws its material impartially from ancient and modern, civilized and primitive communities (I9II: 580 ). In this way comparative jurisprudence formed a link between the study of social institutions in primitive, archaic, and medieval societies. And indeed when Vinogradoff came to list the major figures involved, he included lawyer-anthropologists like McLennan, Bachofen, and Morgan, the great Semitic scholar, Robertson Smith, the Romanist von Ihering, as well as other major figures in the history of anthropology, such as E. B. Taylor and J. G. Frazer. Frazer's work has of course influenced many writers on medieval subjects, particularly in the literary field, and while not all the results have been entirely happy the author of The Golden Bough can claim some credit for the theme of Marc Bloch's Les Rois thaumaturges (1924). Again the whole body of work on village communities, in particular the analysis of Early AngloSaxon and Celtic society undertaken by Frederic Seebohm (1883, 1895, 1902), stemmed from this same tradition. ${ }^{23}$

Thus medieval studies have been influenced in a variety of ways by comparative jurisprudence, which in its turn has had a direct link with social anthropology, or what some of us would prefer to call comparative sociology. The link continues tuday. Students of anthropology still study Maine, Fustel de Coulanges, and Vinogradoff, as well as the writings of the major figures in sociology. I make this point in order to suggest that the work of some of the outstanding medieval scholars (and of classicists too) has already come into contact with comparative sociology in one form or another, so that one can only expect gains of a limited kind when the insights derived from their work are fed back into studies of African societies.

But, while the reverse is perhaps even more true, Africanists certainly have something to learn from the studies of medieval historians. Firstly, the work of Maitland, for example, is full of acute observations on topics like inheritance, marriage, descent, which provide valuable material for comparative analysis quite apart from the question of whether 'feudal' institutions were present in Africa. Secondly, when dealing with centralized political systems, the anthropologist often acts as a special kind of

:3 'Mr Seebohm's English Village Community' . . revealed to us, for the first time, the inner life of mediaeval England.' (W. J. Ashley, 'The English Manor', introductory chapter to N. D. Fustel de Coulanges, The Origin of Property in Land (Ist pub. 1889), trans. by Margaret Ashley, I $89 \mathrm{I}$, xii-xiii.) There have of course been many criticisms of the 'tribal' school: Fustel de Coulanges's essay on property is one of these. Seebohm's work 'profoundly shocked the learned world of the day' (Stephensun, I954: 24I, n. 23) and both Vinogradoff's Villainage in England (1892) and Maitland's Domesday Book and Beyond ( 1897 ) were partly inspired by the desire to refute his thesis that English history 'begins with the serfdom of the masses' (Seebohm, $188_{3}: \mathrm{ix}$ ). For a more specific comment on Seebohm's use of sources, see Timothy Lewis, 'Seebohm's Tribal System of Wales', Economic History Rerien, 1x (2nd ser., 1956-7), 10-33. 
sociological historian. He records the tables of old men; he may even administer questionnaires, like Maquet did in his Ruanda study. But if it is the indigenous system he is interested in, he cannot do what he does for marriage, household composition, and the like; he cannot go out and observe an independent State in action. It follows that if the anthropologist has to reconstruct the past in this way then he should know something of the procedures of the ordinary graphohistorian. ${ }^{24}$ The prospect of this course of indoctrination need not be too overwhelming. As much nonsense is talked about the techniques of the historian as about the methods of the sociologist-and with somewhat less reason.

Today the positive achievements of the writers in the field of historical jurisprudence seems to lie not so much in their grand picture of the development of social organization (although this matter was certainly of considerable importance in their work), but rather in the study of particular customs and concepts in a wide setting and in the attempt to establish interrelationships between the institutions which they isolated in this way. As instances of this work I would cite Maine on the relationship between ancestor-worship and inheritance ( 1883 ) and Vinogradoff on the connexions between types of agriculture and family composition (1920: I, 292).

If we are to take up and develop the tradition of comparative work, which has been so neglected in recent years by historians, sociologists and anthropologists alike, then the best strategy at this stage is to avoid the kind of overall comparisons that are invited by words like tribalism, feudalism, capitalism. These abstractions make for too crude a level of analysis. Social anthropologists are sometimes surprised at the sort of statements historians make about the social organization of African societies, just as traditional historians often raise their brows at the kind of remark sociologists make about the Reformation and medieval Europe. We must avoid not only historical particularism, but also ill-considered generalities.

So far progress in the comparative study of centralized institutions in Africa has not been great; ${ }^{25}$ the material is complex and compared with the study of lineage systems, for example, it has had little systematic attention. All the more need then for a considered approach.

How should this be tackled? We need first of all to concentrate upon the

${ }^{81}$ I use this term to make a distinction with the ethnohistorian. Ethnohistory usually refers to a study of the past which involves not only written records but also oral traditions, informant's versions of recent events as well as data of an archaeological and ethnological character. As there is a danger among traditional historians of assuming that a widely based study of this kind is in some sense inferior to a study resting upon documents alone, it seems desirable (particularly in the context of African studies) to use a word that avoids the opposition 'history-ethnohistory' and at the same time indicates the limitations of a method which ties itself exclusively to writing. Hence 'graphohistory'.

${ }^{25}$ Apart from monographs of theoretical interest and the general works by Fortes and Evans-Pritchard (1940), Schapera (1956), and Mair (1962) some interesting studies have been on a more particular level. There is Beattie's analysis of checks and balances (1959), Colson's discussion of bureaucracy (r 958 ), Gluckman's work on rituals of rebellion (1954) which has led to much discussion and research, Richards's papers on the role of royal relatives ( 1961 ) and the social mechanisms for the transfer of political rights (1960). 
analysis of particular institutions, so that we can try to select the other factors with which they are associated. This means more than simply offering a definition of, say, 'clientship'. The process of constructing analytic concepts should involve spelling out the range of social behaviour implied and the alternative possibilities for human action. ${ }^{26}$ If possible, it should also allow for 'measurement'; that is, for an assessment of gradients of differentiation and thus avoid commitment to a simple typology. And refinements of this kind are necessary, whether we are interested in comparing the differences and similarities of various social systems, or in discerning the sequences and explanation of social change. Until more work of this kind is done, the question 'Feudalism in Africa?' has little meaning, except for polemical purposes.

There is, however, a related problem of historical interest where recent sociological studies can help to clear away some of the cobwebs. This is the problem of state formation. African historians, even the 'ethnos', have been more or less exclusively concerned with centralized political systems, and for understandable reasons; in general, societies without rulers are societies without history, and hence without historians. In Fage's Atlas of African History, for example, the diagrams are almost entirely of states. Plotted on a map, these units show a clustered but discontinuous distribution which invites questions about their point of origin and manner of diffusion. These are reasonable enough questions. But to answer them we need evidence, and of this there is little. If we have to make do with guesses, then these should be as well informed as possible. Recent studies of African states make it clear that while increased centralization in the political system often results from conquest, it is not only in this way that states arise. The Alur, for example, extend their domination when neighbouring peoples invite their chiefs to come and rule over them; we find, in effect, an upward delegation of authority rather than the assumption of power by a military dominant group.

Nor is diffusion, peaceful or violent, the only means. For if we modify the dichotomy between chiefless and state systems by introducing the idea of a gradient of centralization, as has been suggested by M. G. Smith (1956), Easton (1959), Mair (1962), and others, then the nucleus of state systems can be discerned even among the lineages, age-sets, cult-associations, and other basic groupings of acephalous societies. ${ }^{27}$ The question of

${ }^{26}$ Boutruche makes a start on this by undertaking the study of 'ties of subordination' in Frankish Europe and outside. He concludes his book with the following remarks upon the general question of feudalism: 'La féodalité est médiévale. Elle ne doit rien à l'Afrique, rien sans doute à l'Asie, le Japon excepté. Elle est fille de l'Occident' (1959: 297).

${ }^{27}$ I do not mean to suggest, as others have recently done, that the dichotomy between 'acephalous' and 'state' systems is 'almost useless'. Even if one restricts the discussion to the apparatus of authority (in the Weberian sense), there are clearly great differences as one moves between societies at the Tallensi-Nuer end of the continuum, and those at the Ashanti-Nupe end. 'Acephalous' systems are not without holders of authority, but their jurisdiction is limited in terms of the numbers of persons involved and the activities covered; moreover, the methods of social control differ in emphasis from those employed in centralized societies. 
diffusion then assumes less importance in the total picture, for this nucleus needs only the right conditions to develop into a more centralized organization.

A variety of factors suggest themselves here. In West Africa I have been impressed with the apparent ease with which small-scale, temporary systems of a centralized kind arose around (or in opposition to) the raiders for slaves and booty during the period immediately prior to the coming of the Europeans. ${ }^{28}$ Then again, while the exchange of goods took place among and across peoples who lacked chiefs, long-distance trade was certainly facilitated by the presence of rulers, and did a good deal to encourage their growth.

These investigations suggest that any idea of the diffusion of kingship or chiefship from a single source, Egypt or elsewhere, should be treated with great reserve. Of course particular state systems have spread and undergone modifications in the process, by conquest and by other means. But before one can seriously entertain a hypothesis of diffusion based simply on the existence of supposed similarities, the criteria of comparison need to be carefully specified. 'Kingship' itself is much too vague. And to add the epithet 'divine' does little to help. We would expect any monarch that arose in Africa to be strongly linked to the religious system, whether it arose in response to local conditions or was created by some process of diffusion.

It is partly this multiplicity of modes of state formation which makes the formulation of the main lines of political development so difficult. That the history of man in the various parts of the world has been marked by a number of broadly similar developments in political institutions is a proposition that few would now wish to deny. In general this progression is seen as one from less to more complex forms of organization; the doctrine that the manners of simple peoples represent decadent remnants cast off by more advanced nations, the customs of those who have fallen from God's grace, no longer occupies the serious attention it did in $187 \mathrm{r}$ when $\mathrm{E}$. B. Tylor published his notable contribution to the study of cultural evolution, Primitive Culture.

All would agree now that, despite the hopes of some Utopian writers, there has been a general change from small-scale acephalous polities to large-scale centralized states. Beyond this there is little consensus. The contemporary world situation is in itself a denial of the assumption of many Europeans that there would everywhere be an inevitable progression towards parliamentary democracy.

Then again there is the fact that not all social developments, even in the field of technology, have always been in one direction. For there have been

28 The histories of Samori, Babatu, and, on a much smaller scale, Bayuo of Ulu (Dagaba, northern Ghana) provide examples from the Voltaic area in the late nineteenth century. Southall describes the case of a man belonging to an acephalous society who entered the slave trade and posed as a chief (n.d.: $235-6$ n.1). 
many cases where the useful arts have fallen into decay ${ }^{29}$ and where political systems have adopted less centralized forms. In Asia, Leach sees the Kachin of Burma as oscillating in a sort of cyclical fashion between acephaly and monarchy (1954). And in East as in West Africa, slaveraiding gave rise to a number of temporary small-scale, centralized polities which later collapsed. While often, as among the Gonja of northern Ghana, we come across the instance of a conquest state which has become more diffuse and locally centred in its system of government.

But despite these qualifications, and despite the many and often justified criticisms of the application of evolutionary doctrine to social facts, only a real flat-earther would now regard the overall history of political systems as static, cyclical, regressive, indeed as anything other than a process of elaboration.

These questions concerning the origin and spread of state institutions and the rise and fall of different types of polity are ones upon which recent research offers some help. The extent to which the developments in Africa resembled those that occurred in Western Europe is certainly worth pursuing and could even shed some light on the major historical problems that engaged the attention of Marx and Weber. But in this, as in other comparative work, we must start with less worn counters, with more operational concepts. Otherwise the embrace of feudalism, far from leading to a hypergamous union of the desired respectability, will only end in an unhappy hypogamy.

\section{REFERENCES}

African 'Feudalism'.

Busia, K. A. 1951. The Position of the Cilief in Ashanti. London.

Chilver, Mrs E. M. 1960. "Feudalism" in the Interlacustrine Kingdoms', East African Chiefs (ed. Audrey Richards). London.

Davidson, Basil. 196r. Black Mother. London.

Fallers, Lloyd A. n.d. (1956). Bantu Bureaucracy. Cambridge. 1961. 'Are African cultivators to be called "peasants"?' Current Anthropology", II, 108 -io.

Lombard, J. 1957. 'Un système politique traditionnel de type féodal: les Bariba du Nord-Dahomey. Aperçu sur l'organisation sociale et le pouvoir central.' Bull. I.F.A.N., ${ }_{46}^{6}-506$.

1960. 'La vie politique dans une ancienne société de type féodal: les Bariba du

Dahomey.' Cahiers d'études africaines, III, 5-45.

Mair, Lucy P. 1961. 'Clientship in East Africa', Cahiers d'études africaines, II, 315-25.

1962. Primitive Government. London.

29 See Rivers, 1912. A most striking instance of this process was the apparent disappearance of writing in Greece between 1100 and 800 B.C. 
Maquet, Jacques J. 1954. Système des relations sociales dans le Ruanda ancien. Tervuren. 196ra. The Premise of Inequality in Ruanda. London.

I96Ib. 'Une hypothèse pour l'étude des féodalités africaines', Cahiers d'études africaines, II, 292-314.

Nadel, S. F. 1942. A Black Byzantium. London.

Potekhin, I. I. I960. On Feudalism of the Ashanti, paper read to Twenty-fifth International Congress of Orientalists, Moscow.

Rattray, R. S. 1923. Ashanti. London.

1929. Ashanti Law and Constitution. London.

Smith, M. G. 1960. Government in Zazzau. London.

Southall, A. W. n.d. (1956). Alur Society. Cambridge.

\section{Medieval Feudalism.}

Barlow, Frank. 196r. The Feudal Kingdom of England, 1042-1216. (Ist ed. 1955.) London.

Bloch, Marc. 196r. Feudal Society. (French ed. 1939-40.) London.

Boutruche, Robert. I959. Seigneurie et féodalité. Paris.

Coulborn, Rushton (ed.). 1956. Feudalism in History. Princeton.

Ganshof, F. L. 1952. Feudalism. (Belgian ed. 1944.) London.

Hoyt, Robert S. 1961. Feudal Institutions: Cause or Consequence of Decentralization? New York.

Maitland, F. W. 1897 . Domesday Book and Beyond. Cambridge.

Marx, Karl. 1845-6. Die Deutsche Ideologie. (Trans. in Karl Marx: Selected Writings in Sociology and Social Philosophy, T. B. Bottomore and Maximilien Rubel.) London, 1956.

Pollock, F. and Maitland, F. W. 1898. The History of English Law, 2 vols. (2nd ed.) Cambridge.

Stenton, F. 1961. The First Century of English Feudalism, 1066-1166. (1st ed. 1932.) Oxford.

Stephenson, Carl. 1942. Mediaeval Feudalism. Ithaca.

1954. Mediaeval Institutions. Ithaca.

Strayer, Joseph R. 1956. 'Feudalism in Western Europe', in Feudalism in History (ed. Rushton Coulborn). Princeton.

Vinogradoff, Paul. 1892. Villainage in England. London.

Weber, Max. 1947. The Theory of Social and Economic Organization (trans. by A. R. Henderson and Talcott Parsons). Edinburgh.

Other References.

Beattie, J. H. M. 1959. 'Checks on the Abuse of Political Power in some African States', Sociologus, Ix, 97-1 15.

Colson, Elizabeth. 1958. 'The Role of Bureaucratic Norms in African Political Structures', in Systems of Political Control and Bureaucracy in Human Societies (ed. Verne F. Ray), Proc. Am. Eth. Soc., Seattle.

Evans-Pritchard, E. E. 1961. Anthropology cri History. Manchester.

Easton, David. 1959. 'Political Anthropology', in Biennial Review of Anthropology, 1959. Stanford.

Fortes, M. and Evans-Pritctird, J. E. 19t0. African Political Systems. London. 
Fustelde Coulanges, N. D. 1891 . The Origin of Property in Land (trans. Margaret Ashley). London.

Gluckman, Max. 1954. Rituals of Rebellion in South-East Africa. Manchester.

Goody, Jack. 1962. Death, Property and the Ancestors. London.

Lewis, Timothy. 1956-7. 'Seebohm's Tribal System in Wales', Economic History Review (2nd Ser.), x, 16-33.

Maine, Sir Henry. 1883. Dissertations on Early Law and Custom. London.

Richards, A. I. 1960. 'Social Mechanisms for the Transfer of Political Rights in Some African Tribes', f. R. Anthrop. Inst., xc, 175-90.

196r. 'African Kings and their Royal Relatives', $\mathcal{F}$. R. Anthrop. Inst., xCI, 135-50.

Rivers, W. H. R. 1912. 'The Disappearance of Useful Arts', in Festskrift Tillegnad Edvard Westermarck, Helsingfors, I09-1 30.

Schapera, I. 1956. Government and Politics in Tribal Societies. London.

Seebohm, Frederic. 1883. The English Village Community. London.

1895. The Tribal System in Wales. London.

1902. Tribal Custom in Anglo-Saxon Law. London.

Smith, M. G. 1956. 'On Segmentary Lineage Systems', f. R. Anthrop. Inst., LXXXvi, 39-80.

Vinogradoff, Paul. 191 I. 'Comparative Jurisprudence', article in Encyclopaedia Britannica (1 1 th ed.), Vol. 15, 580-7.

1920. Outlines of Historical furisprudence, Vol. I. Introduction-Tribal Law. London. 